\title{
Indonesian students' learning attitude towards online learning during the coronavirus pandemic
}

\author{
Tommy Tanu Wijaya ${ }^{\text {a }}$, Ying Zhou ${ }^{\text {b }}$, Aditya Purnama ${ }^{c}$, Neni Hermita ${ }^{\text {d }}$ \\ Guangxi Normal University. 15 Yucai Road,Qixing District, Guilin, 541004, China \\ a tanuwijayat@gmail.com; b zhouying66@ mailbox.gxnu.edu.cn; ${ }^{\mathrm{c}} 2890174293 @$ qq.com; \\ d neni.hermita@lecturer.unri.ac.id \\ * Corresponding Author
}

Received: 17 September 2020; Revised: 22 September 2020; Accepted: 30 September 2020

\begin{abstract}
Now, the whole world is facing the coronavirus pandemic. In the meantime,students in China are required to do social distancing and not go to school.This coronavirus pandemic in the use of online learning to teach students.This research will get to know the students' learning attitudes towardsonline learning during the coronavirus pandemic. The sample population forthis research is students in West Java, Indonesia. The data will becollected by using questionnaires, and there was a total of 16questionnaires collected for this research. The result of this researchshows that online learning during this coronavirus pandemic is not veryeffective. The students' learning interest in online learning is also low.Based on the interview done on students and teachers, most of them statedthat various factors could affect online learning in China, such as thelearning environment, the internet. The suggestion given in this research isthat aside from online classes, teachers can also use video learning mediathat are used by developed countries to solve the bad internet problem.Hopefully, the result of this research can become a reference for improvinga more effective learning media that can be used during the coronaviruspandemic in Indonesia..
\end{abstract}

Keywords: coronavirus pandemic, learning attitude, online learning, Indonesian students

How to Cite: Wijaya, T., Zhou, Y., Purnama, A., \& Hermita, N. (2020). Indonesian students' learning attitude towards online learning during the coronavirus pandemic. Psychology, Evaluation, and Technology in Educational Research, 3(1), 17-25. doi:http://dx.doi.org/10.33292/petier.v3i1.56

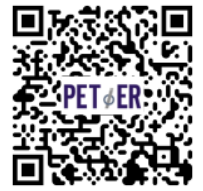

\section{INTRODUCTION}

At the beginning of 2020, the whole world is facing the coronavirus pandemic (COVID-19). The virus is first found in Wuhan, China at the end of 2019 (Cao et al., 2020). This virus causes failure to the humans' respiratory system and it spreads so fast that can even cause death. The initial symptoms of this virus are fever, cold, coughing and a runny nose. Until now, there is no exact information about where the virus came from.

Every country chooses to do a lockdown and social distancing to avoid the virus from spreading. This decision led to various sectors to be paralyzed. Not only the economic sector, but the education sector also faces a big impact from the pandemic. This is because during the corona pandemic, students all around the world are required to stay at home and not go to school until its stabilized. Some countries have developed a learning media and a new teaching method for this corona pandemic (Favale et al., 2020; Kerres, 2020; Peters et al., 2020; Zhu \& Liu, 2020).

In China, the coronavirus patient increases daily and during this corona pandemic, teachers have no other choice but to use technology such as video learning or online learning to teach students. In other words, this can be an opportunity for teachers to learn how to use technology to teach, hoping that after this corona pandemic, teachers' skill in using technology-based learning media can improve.

The development of technology in the $21^{\text {st }}$ century has become an important role (Flogie et al., 2018; Ilmi et al., 2020). Technology can help people with their work in various fields that includes the education field (Puloo et al., 2018; Purwaningsih et al., 2019). Knowing the importance of technology in the education field, mathematics teachers are required to master and develop a technology-based learning media (Chatmaneerungcharoen, 2019; Hernawati \& Jailani, 2019; Listiawan et al., 2018). At 
least, teachers can use the learning media to teach during class time (Wijaya, Ying, \& Suan, 2020b). When the teacher uses a learning media, it can increase the students' interest in learning (Arrosagaray et al., 2019; Divaharan \& Ping, 2010; Putri \& Prodjosantoso, 2020). Other than that, research shows that using technology in class can improve the students' learning outcome significantly (Hermawan et al., 2018; Mushipe \& Ogbonnaya, 2019; Peeraer \& Van Petegem, 2012). It will enable students to easily understand the mathematics concept taught (Kubiatko et al., 2010). With the help of technology, teachers can explain mathematics concept that is hard to show such as what is the probability of the number 6 appearing in 505 dice throws or what is the probability of getting ahead in 1003-coin throws.

Several countries have implemented a distance learning system. There have been many learning media developed during the corona pandemic as a solution for teaching and learning activities in schools (Ichsan et al., 2020; Manullang \& Satria, 2020; Putra et al., 2020; Wijaya, 2020). It is hoped that the corona pandemic will not interfere with the teaching and learning process of students both in elementary schools and universities. Until now, conditions in Indonesia have not shown any signs of improvement. On this occasion, the researcher wanted to conduct research on student attitudes towards online learning in Indonesia. With the hope that the results of this research can be a suggestion for the development of learning media in Indonesia. So that teaching and learning activity in class can be even better.

Previous research conducted in West Java (Fauzi \& Khusuma, 2020), 73.9\% of teachers said that online learning was not effective. Teachers find many problems when carrying out teaching and learning activities using an online learning system. These problems include (1) school facilities; (2) internet connection; (3) planning, implementation and evaluation of teaching and learning activities. It can be said that teachers are still not ready for the current conditions, and when they have to do online teaching and learning activities during the pandemic. Previous research was taken to see teacher responses to online learning. Then this research will be developed by conducting research on student attitudes towards online learning and providing solutions according to the needs of students and teachers during a pandemic. The online learning has been going for six months and seeing the constant increase in patients, there is a higher chance that the coronavirus pandemic will not be as fast as we expected. In this research, the researchers will research on the students' learning attitude towards online learning during the corona pandemic. The result of this research will serve as a reference to develop the next learning media also can become an evaluation of the online learning that has been used.

\section{METHOD}

This research uses a mix of qualitative and quantitative method. A survey method is one of the techniques to collect data or information by giving out questionnaires to respondents (Wijaya, Ying, \& Suan, 2020c). After collecting data, the data will then be processed to get the respondents' conclusion.

Table 1. Students' statement on their learning attitude towards online learning

\begin{tabular}{ll}
\hline No. & \multicolumn{1}{c}{ Statement } \\
\cline { 2 - 2 } 1. I get lazy when using online learning. & Answer \\
2. Online learning is not very effective. \\
3. I enjoy going to school more than online learning. \\
4. I am very excited during online learning. \\
5. I enjoyed online learning. \\
6. I do not want to hear teachers' explanation during online learning. \\
7. Even though it is online learning, I am still excited to learn. \\
8. I feel sleepy during online learning. \\
9. Going to school and online learning are both effective. \\
10. I feel that online learning is better than going to school. \\
11. Online learning is very interesting. \\
12. I am not very interested in online learning. \\
13. I will pay full attention during online learning. \\
14. I feel like I can understand the topic better during online learning. \\
15. After the corona pandemic, I hope that we still can use online learning. \\
16. Online learning is a good learning method during this corona pandemic.
\end{tabular}




\section{Psychology, Evaluation, and Technology in Educational Research, 3 (1), 2020, 19}

Tommy Tanu Wijaya, Ying Zhou, Aditya Purnama, Neni Hermita

The researchers of this research did an investigation on the students' learning attitude towards online learning in Indonesia during the corona pandemic. The sample of this research are students all over West Java because in Jakarta and West Java, the population is very dense and the place was quite seriously affected during the coronavirus. The questionnaires are given online so that the data collected will be more scattered and evenly distributed to the students in West Java. In this study, researchers took samples randomly in high school in West Java. There was a total of 54 respondents that answered a 16-question questionnaire about their opinion of online learning during the corona pandemic. The questionnaire on the students' attitude towards online learning is shown on Table 1.

The questionnaire questions can be seen in Table 1. A descriptive qualitative analysis will be used to analyze the data. The analysis will be based on the respondents' percentage for each question items. The percentage interpretation of this research can be seen in Table 2.

Table 2. Percentage interpretation of the questionnaire answer

\begin{tabular}{cc}
\hline Interval score $(\%)$ & Criteria \\
\hline $0<\mathrm{x}<25$ & Very Low \\
$26<\mathrm{x}<50$ & Low \\
$51<\mathrm{x}<75$ & High \\
$76<\mathrm{x}<100$ & Very High \\
\hline
\end{tabular}

\section{RESULTS AND DISCUSSIONS}

The questionnaires were distributed to high school students in West Java. The results of the questionnaire were processed using Microsoft Excel and SPSS 19.0 to determine student responses to online learning. Based on these results, the researcher made observations about how other countries do online learning. This method can be used to be applied in Indonesia during the COVID pandemic.

Table 3. Descriptive data on the students' learning attitude towards online learning

\begin{tabular}{clccccccc}
\hline \multirow{2}{*}{$\begin{array}{c}\text { Item } \\
\text { number }\end{array}$} & \multirow{2}{*}{ Type } & Minimum & Maximum & Sum & Std. Dev. & \multicolumn{2}{c}{ Mean } & \multirow{2}{*}{ percentage } \\
\cline { 2 - 6 } & & Statistic & Statistic & Statistic & Statistic & Statistic & Std. Error & \\
\hline 1. & Negative & 1.00 & 3.00 & 328.00 & .67708 & 2.6452 & .06080 & $43.13 \%$ \\
2. & Negative & 1.00 & 3.00 & 275.00 & .73871 & 2.2177 & .06634 & $44.44 \%$ \\
3. & Negative & 1.00 & 3.00 & 183.00 & .56257 & 1.4758 & .05052 & $36.90 \%$ \\
4. & Positive & 1.00 & 4.00 & 144.00 & .53171 & 1.1613 & .04775 & $29.03 \%$ \\
5. & Positive & 2.00 & 3.00 & 261.00 & .30759 & 2.1048 & .02762 & $41.62 \%$ \\
6. & Negative & 2.00 & 4.00 & 327.00 & .53091 & 2.6371 & .04768 & $63.93 \%$ \\
7. & Positive & 1.00 & 4.00 & 252.00 & 1.42530 & 2.0323 & .12800 & $49.81 \%$ \\
8. & Negative & 2.00 & 3.00 & 254.00 & .21545 & 2.0484 & .01935 & $48.21 \%$ \\
9. & Positive & 2.00 & 4.00 & 325.00 & .72929 & 3.6129 & .06549 & $34.52 \%$ \\
10. & Positive & 2.00 & 4.00 & 356.00 & .75126 & 3.3871 & .06746 & $39.77 \%$ \\
11. & Positive & 1.00 & 4.00 & 338.00 & 1.33945 & 2.7258 & .12029 & $31.15 \%$ \\
12. & Negative & 1.00 & 4.00 & 332.00 & 1.23991 & 2.6774 & .11135 & $32.94 \%$ \\
13. & Positive & 1.00 & 4.00 & 332.00 & 1.20668 & 2.6774 & .10836 & $30.94 \%$ \\
14. & Positive & 2.00 & 4.00 & 271.00 & .46621 & 2.1855 & .04187 & $54.64 \%$ \\
15. & Positive & 1.00 & 4.00 & 321.00 & 1.47616 & 2.5887 & .13256 & $35.72 \%$ \\
16. & Positive & 2.00 & 4.00 & 388.00 & .99566 & 3.1290 & .08941 & $21.23 \%$ \\
\hline
\end{tabular}

From Table 3, we can see the analysis result on the students' learning attitude towards online learning during the pandemic in Indonesia. This research is divided into 2 parts to know whether the online learning is effective during the pandemic that can be found in questions $2,9,10,14,16$ and about the students' interest towards the online learning that can be found in questions $1,3,4,5,6,7,8$, $11,12,15$.

The students' average percentage response on the effectiveness of online learning during the pandemic is $38.92 \%$. From this percentage, we can see that the online learning is not very effective. At the same time, the students' average percentage response on the learning interest during the corona pandemic is $41.24 \%$ which means that students are also not very interested in the online learning during this corona pandemic.

During this corona pandemic, students in Indonesia are required to do independent studying at home. In Guilin, there are a lot of methods on how to do long-distance learning. Students were able to 
use various studying application for free. Most schools apply the video learning method by using Zoom meeting, Tencent meeting and other meeting conference applications. These applications can be used by teachers so that they would still be able to see the students face-to-face. This way, students will also see the teachers' explanation clearly. We can see students' testimony towards online learning in Table 4.

Table 4. Students' testimony towards online learning

\begin{tabular}{cl}
\hline Students & Statement \\
\hline S1 & I can't understand the topic discussed in online learning. \\
S2 & Online learning resulted in teachers giving more homework. \\
S3 & I can't concentrate on learning at home. \\
S4 & I don't have money to buy the internet. \\
S5 & Internet connection in Indonesia is bad for online learning. \\
S6 & Online learning causes tiredness when staring at the screen. \\
S7 & Online learning makes me lazier. \\
S8 & I fell online learning is not as effective as going to school. \\
\hline
\end{tabular}

In Table 4, we can see that there are a lot of complaints from the students towards online learning. In general, we can conclude that students feel that learning using video learning is less effective than learning in school. Some of the factors that affect this online learning in West Java is the internet connection, learning environment not met, the side effect of electronic gadget towards their health. A lot of them are hoping that this corona pandemic can pass quickly so that they would be able to go back to school.

The researchers also conducted an interview to know the teachers' response towards online learning during this corona pandemic. As we can see in Table 5, teachers think that online learning during this corona pandemic have both positive and negative effect. Even though most teachers feel that the preparation of material is much more tiring than normal, but teachers feel that it can improve their skills in using a technology-based learning media. This corona pandemic forces them to learn how to use a technology-based learning media to prepare their teaching material. This way, even after the corona pandemic ends, they would still improve their skill in using a technology-based learning media to improve students' learning outcome.

Table 5. Teachers' response towards online learning

\begin{tabular}{cl}
\hline Teacher & statement \\
\hline T1 & Preparing teaching material during the corona pandemic is more tiring. \\
T2 & I have difficulties in disciplining students during online learning. \\
T3 & I have difficulties in observing students' seriousness during the online learning. \\
T4 & I am confused about which teaching method or approach that should be used during online learning. \\
T5 & The internet connection in Indonesia can't really support online learning. \\
T6 & The corona pandemic made me learn on how to use a technology-based learning media.
\end{tabular}

As seen in Figure 1, the most effective long-distance learning method used in Indonesia is by using a webcam application. By taking advantage of the technology that is rapidly growing, the teaching-learning activity won't stop even if students are not going to school. Actually, this longdistance learning method won't be a problem if teachers, students and parents are able to cooperate so that this learning method can work during this corona pandemic. Teachers can prepare teaching materials that are suitable for the long-distance learning method, wherein the learning would be shorter and concentrate on the basic concept of the topic taught. Teachers are also required to use an approachable and interesting teaching method so that students won't feel bored during online learning. Online learning is also a new experience for students so some students probably think that is not effective and boring because can't learn normally. However, if the students are able to work together and try to study independently, researchers believe that even if it's online learning, students would still be able to study properly. Parents also have an important role in the success of this online learning as parents can give attention and support for their children. With this, not only that students are able to learn properly using online learning, but the parent-child relationship can be closer. The support from parents is believed to be able to help their child grow. 


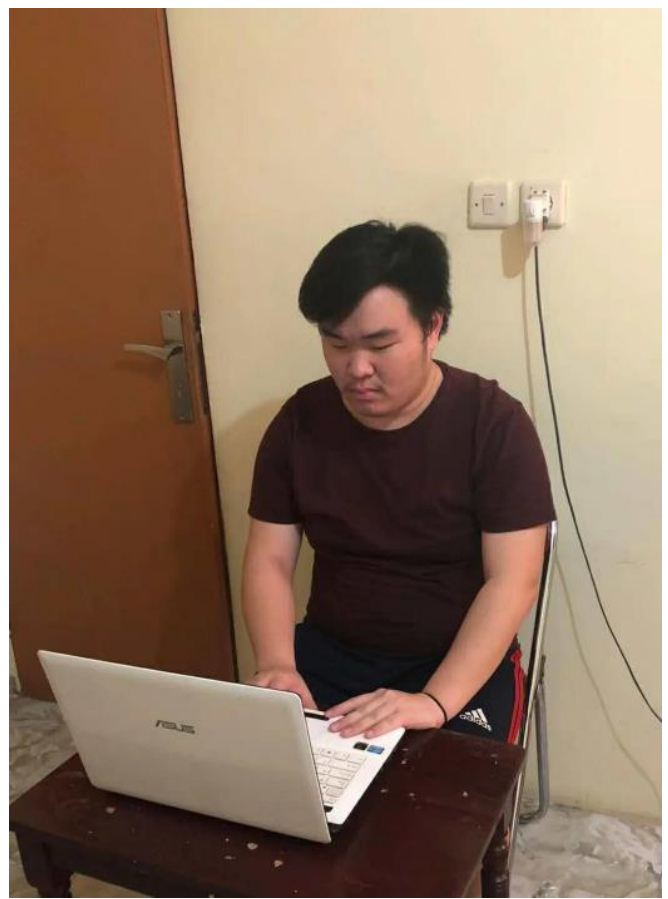

Figure 1. Student doing online learning at home

Now we just need to wait until the corona pandemic ends. We can see that this corona pandemic has both negative and positive impacts in various aspects. One of the positive impacts in the education field is that we can develop a technology-based learning media. There has been various research that shows that a technology-based learning media can help improve students' skill, learning outcome, learning motivation, self-confidence and other skills (Fani \& Sukoco, 2019; Putri \& Prodjosantoso, 2020; Wijaya, Ying, Chotimah, et al., 2020a). So, by the end of the pandemic, there will be some positive impacts on the learning media development that can be used to improve the students' learning skills in other developing countries.

After analyzing how students in developed countries such as America studied during the corona pandemic, we can develop a long-distance learning media in the form of video learning. One of the video learning that is use in China is Hawgent dynamic mathematics software's video learning as we can see in Figure 2. Hawgent's video learning has helped students to learn mathematics during this corona pandemic. Students from Guangxi Normal University and Professor Tang Jianlan has developed over 50 video learning using Hawgent dynamic mathematics software to support students learning mathematics during this pandemic.

Hawgent dynamic mathematics software is currently the most powerful mathematics education platform in China and have also been recognized in other countries as a magic weapon to help teach difficult mathematics problems (Wijaya, Ying, \& Purnama, 2020a). Some of its main characteristics is the ability to make dynamic demonstrations, making knowledge points more intuitive and making learning mathematics more interesting and easier to understand. In fact, Hawgent dynamic mathematics software is integrated into mathematics teaching which is a good assistant in solving difficulties in mathematics teaching (Cunhua et al., 2019). There are a lot of research that shows that Hawgent can improve the students' mathematical ability both soft and hard skills (Lin et al., 2020; Wijaya et al., 2020 , 2020). Other than that, students would be able to easily understand the basic concept when the topic is given using Hawgent dynamic mathematics software compared to traditional teaching method (Tan et al., 2020; Wijaya, Ying, \& Purnama, 2020b). Based on the research results, a good instructional video has a duration of 5-10 minutes. Video-based learning with a duration that is not too long will increase the curiosity of students to find out the next learning video. If the video learning is too long, the students will be tired and sleepy, which will reduce the students' learning concentration (Daniel, 2020). Right now, Hawgent dynamic mathematics software are used as a long-distance learning media in the form of video learning that ranges from 5-10 minutes long that can be use during the pandemic. 


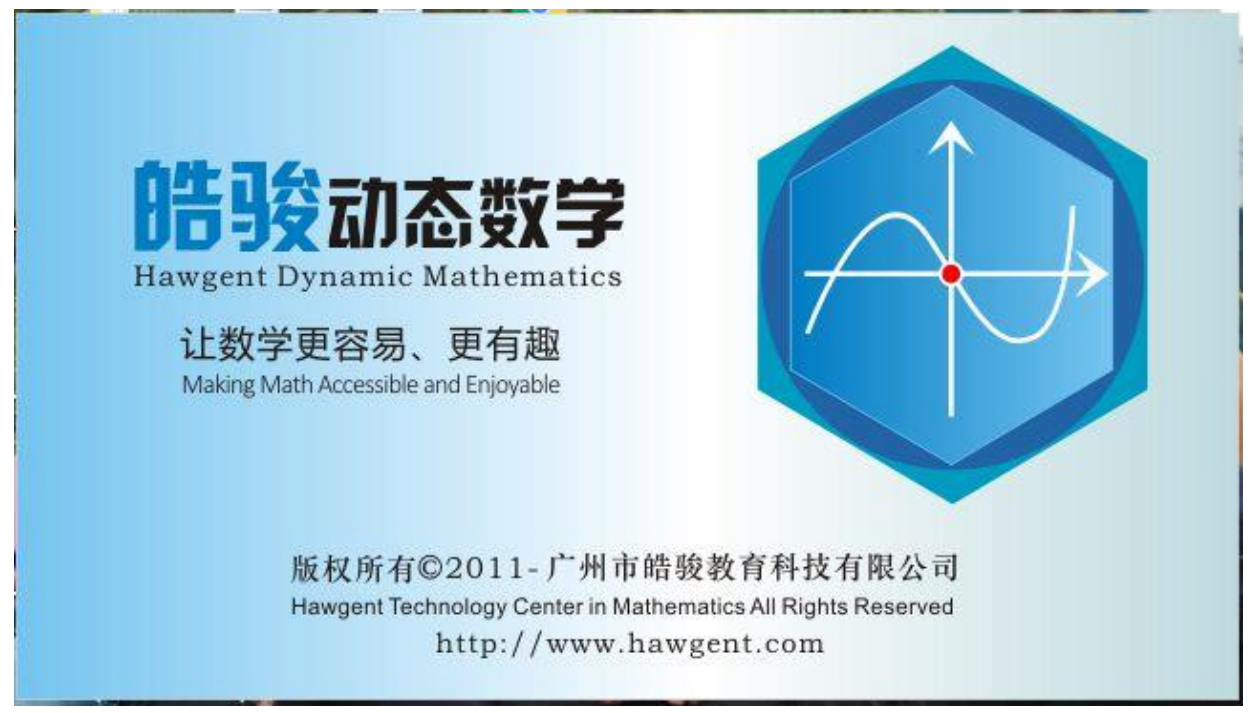

Figure 2. Hawgent dynamic mathematics software

Future researches can use this data to develop a long-distance learning media that can be used in China during the corona pandemic or develop learning media that can overcome the problems described above like Learning media that do not require a lot of internet connection as well as effective learning media even though students do not go to school to study. This way, the teaching-learning process in China can be more effective during the corona pandemic. It would be better to use this application to see the progress of Indonesian students' achievement and motivation in learning mathematics.

\section{CONCLUSION}

The coronavirus pandemic has affected all sectors that include the education sectors. In Indonesia, students are unable to go to school to study. During this corona pandemic, students learn from home and teachers prepare a long-distance learning method. One of the learning methods used in China is online learning. Based on the questionnaire result, most students feel that online learning is not effective and boring. Some of the complaint stated by the students are the environment influence and the internet connection that can't fully support the online learning. Based on the interview done to the teachers, they also stated that online learning is not easy as it needed a lot of preparation and the internet connection are some of the factor to a successful online learning. Hopefully this research can help develop a learning media that are more effective to be use during the coronavirus pandemic in Indonesia.

\section{ACKNOWLEDGEMENT}

Researchers would like to say thank you for all students who have to be respondents in this research as well as to the University of Riau who has supported this research to run well. We also would like to thanks to Guangxi Normal University for the research fund which has been given to the researcher. In 2019, Guangxi Higher Education Undergraduate Teaching Reform Project "research and practice of effective mathematics teaching guided by systematic thinking ability" (Project No.: 2019JGZ110); in 2020, Guangxi Graduate Education Innovation Plan Project "Research on training mode of improving high-level thinking ability" (Project No.: XJGY2020010).

\section{REFERENCES}

Arrosagaray, M., González-Peiteado, M., Pino-Juste, M., \& Rodríguez-López, B. (2019). A comparative study of Spanish adult students' attitudes to ICT in classroom, blended and distance language learning modes. Computers \& Education, 134(October 2018), 31-40. https://doi.org/10.1016/j.compedu.2019.01.016

Cao, W., Fang, Z., Hou, G., Han, M., Xu, X., Dong, J., \& Zheng, J. (2020). The psychological impact of the COVID-19 epidemic on college students in China. Psychiatry Research, 287(March), 


\section{4. https://doi.org/10.1016/j.psychres.2020.112934}

Chatmaneerungcharoen, S. (2019). Improving Thai science teachers' TPACK through an innovative continuing professional development program. Journal of Physics: Conference Series, 1340(1), 012017. https://doi.org/10.1088/1742-6596/1340/1/012017

Cunhua, L., Ying, Z., Qunzhuang, O., \& Wijaya, T. T. (2019). Mathematics course design based on six questions cognitive theory using hawgent dynamic mathematic software. Journal On Education, 2(1), 36-44. http://jonedu.org/index.php/joe/article/view/266

Daniel, S. J. (2020). Education and the COVID-19 pandemic. PROSPECTS, 0123456789. https://doi.org/10.1007/s11125-020-09464-3

Divaharan, S., \& Ping, L. C. (2010). Secondary school socio-cultural context influencing ICT integration: A case study approach. Australasian Journal of Educational Technology, 26(6), 741-763. https://doi.org/10.14742/ajet.1040

Fani, R. A., \& Sukoco, P. (2019). Volleyball learning media using method of teaching games for understanding adobe flash-based. Psychology, Evaluation, and Technology in Educational Research, 2(1), 34-50. https://doi.org/10.33292/petier.v2i1.6

Fauzi, I., \& Khusuma, I. H. S. (2020). Teachers' elementary school in online learning of COVID-19 pandemic conditions. Jurnal Iqra' : Kajian Ilmu Pendidikan, 5(1), 58-70. https://doi.org/10.25217/ji.v5i1.914

Favale, T., Soro, F., Trevisan, M., Drago, I., \& Mellia, M. (2020). Campus traffic and e-Learning during COVID-19 pandemic. Computer Networks, 176(April), 107290. https://doi.org/10.1016/j.comnet.2020.107290

Flogie, A., Lakota, A. B., \& Aberšek, B. (2018). The psychosocial and cognitive influence of ICT on competences of STEM students. Journal of Baltic Science Education, 17(2), 267-276. http://www.scientiasocialis.lt/jbse/files/pdf/vol17/267-276.Flogie_JBSE_Vol.17_No.2.pdf

Hermawan, H., Samsuri, S., Kurniawati, D. P., Sofyaningsih, V., \& Prasetyo, D. (2018). The use of controversial public issues with video and macromedia flash player media in civic education learning. Psychology, Evaluation, and Technology in Educational Research, 1(1), 19. https://doi.org/10.33292/petier.v1i1.2

Hernawati, K., \& Jailani. (2019). Mathematics mobile learning with TPACK framework. Journal of Physics: Conference Series, 1321(2), 022126. https://doi.org/10.1088/17426596/1321/2/022126

Ichsan, I. Z., Rahmayanti, H., Purwanto, A., Sigit, D. V., Miarsyah, M., \& Gomes, P. W. P. (2020). HOTS-AEP-COVID-19 and ILMIZI learning model: The 21st-Century environmental learning in senior high school. JPBI (Jurnal Pendidikan Biologi Indonesia), 6(2). https://doi.org/10.22219/jpbi.v6i2.12161

Ilmi, A. M., Sukarmin, \& Sunarno, W. (2020). Development of TPACK based-physics learning media to improve HOTS and scientific attitude. Journal of Physics: Conference Series, 1440(1), 012049. https://doi.org/10.1088/1742-6596/1440/1/012049

Kerres, M. (2020). Against all odds: Education in Germany coping with Covid-19. Postdigital Science and Education, 2(3), 690-694. https://doi.org/10.1007/s42438-020-00130-7

Kubiatko, M., Usak, M., Yilmaz, K., \& Tasar, M. F. (2010). A cross-national study of Czech and Turkish university students' attitudes towards ICT used in science subjects. Journal of Baltic Science Education, 9(2), 119-134. http://www.scientiasocialis.lt/jbse/?q=node/193

Lin, S., Zhou, Y., \& Wijaya, T. T. (2020). Using hawgent dynamic mathematics software in teaching arithmetic operation. International Journal of Education and Learning, 2(1), 25-31. https://doi.org/10.31763/ijele.v2i1.97

Listiawan, T., Purwanto, As'ari, A. R., \& Muksar, M. (2018). Mathematics teachers technological content knowledge (TCK) in using dynamic geometry software. Journal of Physics: Conference Series, 1114(1), 012121. https://doi.org/10.1088/1742-6596/1114/1/012121

Manullang, S. O., \& Satria, E. (2020). The review of the international voices on the responses of the worldwide school closures policy searching during Covid-19 pandemic. Jurnal Iqra' : Kajian 
Psychology, Evaluation, and Technology in Educational Research, 3 (1), 2020, 24

Tommy Tanu Wijaya, Ying Zhou, Aditya Purnama, Neni Hermita

Ilmu Pendidikan, 5(2), 1-13. https://doi.org/10.25217/ji.v5i2.1036

Mushipe, M., \& Ogbonnaya, U. I. (2019). Geogebra and grade 9 learners' achievement in linear functions. International Journal of Emerging Technologies in Learning (IJET), 14(08), 206. https://doi.org/10.3991/ijet.v14i08.9581

Peeraer, J., \& Van Petegem, P. (2012). The limits of programmed professional development on integration of information and communication technology in education. Australasian Journal of Educational Technology, 28(6), 1039-1056. https://doi.org/10.14742/ajet.809

Peters, M. A., Wang, H., Ogunniran, M. O., Huang, Y., Green, B., Chunga, J. O., Quainoo, E. A., Ren, Z., Hollings, S., Mou, C., Khomera, S. W., Zhang, M., Zhou, S., Laimeche, A., Zheng, W., Xu, R., Jackson, L., \& Hayes, S. (2020). China's internationalized higher education during Covid-19: Collective student autoethnography. Postdigital Science and Education, 2(3), 968-988. https://doi.org/10.1007/s42438-020-00128-1

Puloo, M. M. L., Juniati, D., \& Wijayanti, P. (2018). Visualization profile of junior high school students in solving geometry problems viewed from gender differences. Journal of Physics: Conference Series, 1108(1), 012063. https://doi.org/10.1088/1742-6596/1108/1/012063

Purwaningsih, E., Nurhadi, D., \& Masjkur, K. (2019). TPACK development of prospective physics teachers to ease the achievement of learning objectives: A case study at the State University of Malang, Indonesia. Journal of Physics: Conference Series, 1185(1), 012042. https://doi.org/10.1088/1742-6596/1185/1/012042

Putra, P., Liriwati, F. Y., Tahrim, T., Syafrudin, S., \& Aslan, A. (2020). The students learning from home experiences during Covid-19 school closures policy in Indonesia. Jurnal Iqra': Kajian Ilmu Pendidikan, 5(2), 30-42. https://doi.org/10.25217/ji.v5i2.1019

Putri, M. A., \& Prodjosantoso, A. K. (2020). Improving critical thinking skills and scientific attitudes by using comic. Psychology, Evaluation, and Technology in Educational Research, 2(2), 69. https://doi.org/10.33292/petier.v2i2.13

Tan, S., Zou, L., Wijaya, T. T., \& Dewi, N. S. S. (2020). Improving student creative thinking ability with problem based learning approach using hawgent dynamic mathematics software. Journal on Education, 2(4), 303-312. https://doi.org/10.31004/joe.v2i4.324

Wijaya, T. T. (2020). How Chinese students learn mathematics during the coronavirus pandemic. IJERI: International Journal of Educational Research and Innovation, 15(15), 1-16. https://doi.org/10.46661/ijeri.4950

Wijaya, T. T., Purnama, A., \& Tanuwijaya, H. (2020). Pengembangan media pembelajaran berdasarkan konsep Tpack pada materi garis dan sudut menggunakan hawgent dynamic mathematics software. JPMI - Jurnal Pembelajaran Matematika Inovatif, 3(3), 205-214. https://doi.org/10.22460/jpmi.v1i3.205-214

Wijaya, T. T., Sukma, M., Purnama, A., \& Tanuwijaya, H. (2020). Pengembangan media pembelajaran berbasis tpack menggunakan hawgent dynamic mathematics software. Journal of Elementary Education, 03(03), 64-72. https://journal.ikipsiliwangi.ac.id/index.php/collase/article/view/4088

Wijaya, T. T., Ying, Z., Chotimah, S., Bernard, M., Zulfah, Z., \& Astuti, A. (2020a). Hawgent dynamic mathematic software as mathematics learning media for teaching quadratic functions. Journal of Physics: Conference Series, 1592(1), 012079. https://doi.org/10.1088/17426596/1592/1/012079

Wijaya, T. T., Ying, Z., \& Purnama, A. (2020a). The empirical research of hawgent dynamic mathematics technology integrated into teaching fraction in primary school. Jurnal Cendekia : Jurnal Pendidikan Matematika, 4(1), 144-150. https://doi.org/10.31004/cendekia.v4i1.174

Wijaya, T. T., Ying, Z., \& Purnama, A. (2020b). Using hawgent dynamic mathematic software in teaching trigonometry. International Journal of Emerging Technologies in Learning (IJET), 15(10), 215. https://doi.org/10.3991/ijet.v15i10.13099

Wijaya, T. T., Ying, Z., \& Suan, L. (2020b). Using geogebra in teaching plane vector. Journal of Innovative Mathematics Learning, 3(1), 15-23. https://doi.org/10.22460/jiml.v3i1.p15-23 
Psychology, Evaluation, and Technology in Educational Research, 3 (1), 2020, 25

Tommy Tanu Wijaya, Ying Zhou, Aditya Purnama, Neni Hermita

Wijaya, T. T., Ying, Z., \& Suan, L. (2020c). Gender and self regulated learning during COVID-19 Pandemic in Indonesia. Jurnal Basicedu, 4(3), 725-732.

https://doi.org/10.31004/basicedu.v4i3.422

Zhu, X., \& Liu, J. (2020). Education in and after Covid-19: Immediate responses and long-term visions. Postdigital Science and Education, 2(3), 695-699. https://doi.org/10.1007/s42438-02000126-3 